\title{
Graphematic Emblems in Selected Poems by John Hollander \\ Sahar Abdul Ameer Haraj Al-Husseini \\ sahar.abudalameer@qu.edu.iq
}

or

sahar.alhusseini@gmail.com

Al-Qadisyia University- College of Education, Department of English

Submission: 237 at $8 \backslash 6 \backslash 2017$

Abdullah: 525 at $9 \backslash 10 \backslash 2017$

\section{Abstract:}

Graphematic poem or shape poem or pattern poem, like any other poem, is a poem that discusses diverse and common subjects like love, idea, time and many other topics; yet with a certain difference that is the subject is similar to the printed format of the text. To say that it presents a picture of certain familiar object that is similarly the subject of the poem. Such poems are likewise termed shaped verse. They are not new for they are part of a long convention that ranges from Alexandrian Greek poets to Lewis Carroll and beyond. John Hollander(1929 -2013) is an American poet who wrote pattern poetry with a variety of diverse themes . His Types of Shape (1969) offers twenty-five shaped poems in the convention of George Herbert, a seventeenth century English poet.

Graphematic poems must also to a certain degree own their special self-reflective picture in so far as the shape as well as the content are concerned. They show a wide array of themes and Hollander's graphematic poems show fascinating investigates with unbending forms that undermine the authority of his writing. Hollander in uniting content and form supports creating one authoritative outcome in the field of poetry.

\section{الشعارات فهب قصائد مختارة من جون هولاندر سحرعبد الاميرحرج الحسيني جامعة القادسية / كلية التربية - قسم اللغة الانكليزية}

تعد القصيدة التصويرية او الصورية ممانلة لأي قصيدة فهي تتاقش موضوعة الحب والزمن وغيرها الكثير من المواضيع الاخرى المتنوعة ولكن هناللك فرق واحد فقط وهو ان موضوع القصيدة مماثل تماما للشكل الدي تطبع به القصيدة. ويمكن القول انها تمنل صورة لموضوع مألوف جدا وهو مشابه تماما لموضوع القصيدة. وتدعى مثل تلاك

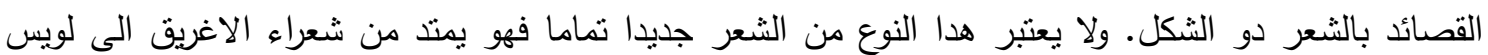

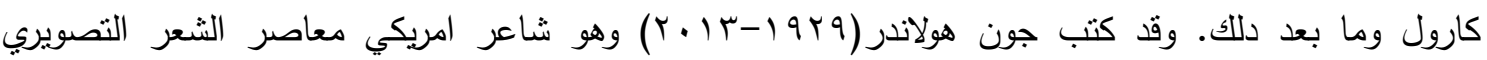
بمواضيع مختلفة ومنتوعة. وقد قدم ديوانه الشعري انواع من الثكل (979 (19) خمس وعشرون قصيدة صورية ضدن تقليد جورج هربرت وهو شاعر من القرن السابع عشر .

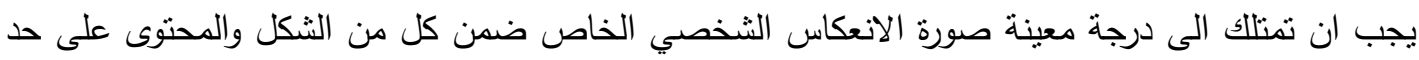
سواء. تتتاول مثل هده القصائد عدد كبير من المواضيع وتوضح قصائد هولاندر التصويرية بحث مميز ضمن اشكال استرخائية تعكس مصداقية ومهارة الثاعر ـ قام هولاندر من خلال توحيد الثكل والمحتوى بدعم ابتكار نتيجة 


\section{Introduction}

"A good poem satisfies the ear. It creates a story or picture that grabs you, informs you and entertains you" John Hollander

John Hollander is among the most distinguished figures of the twentieth century pattern poetry. Hollander in his Types of Shape (1969), presents poems with a design as well as a decoration that recount their subjects, themes, subjects as well as their stories in the cover of a poem. The extensively known poem among Hollander's poems is the mirrored "Swan and Shadow." It is about a sort of depiction of a shape of a swan with its reflection in the water

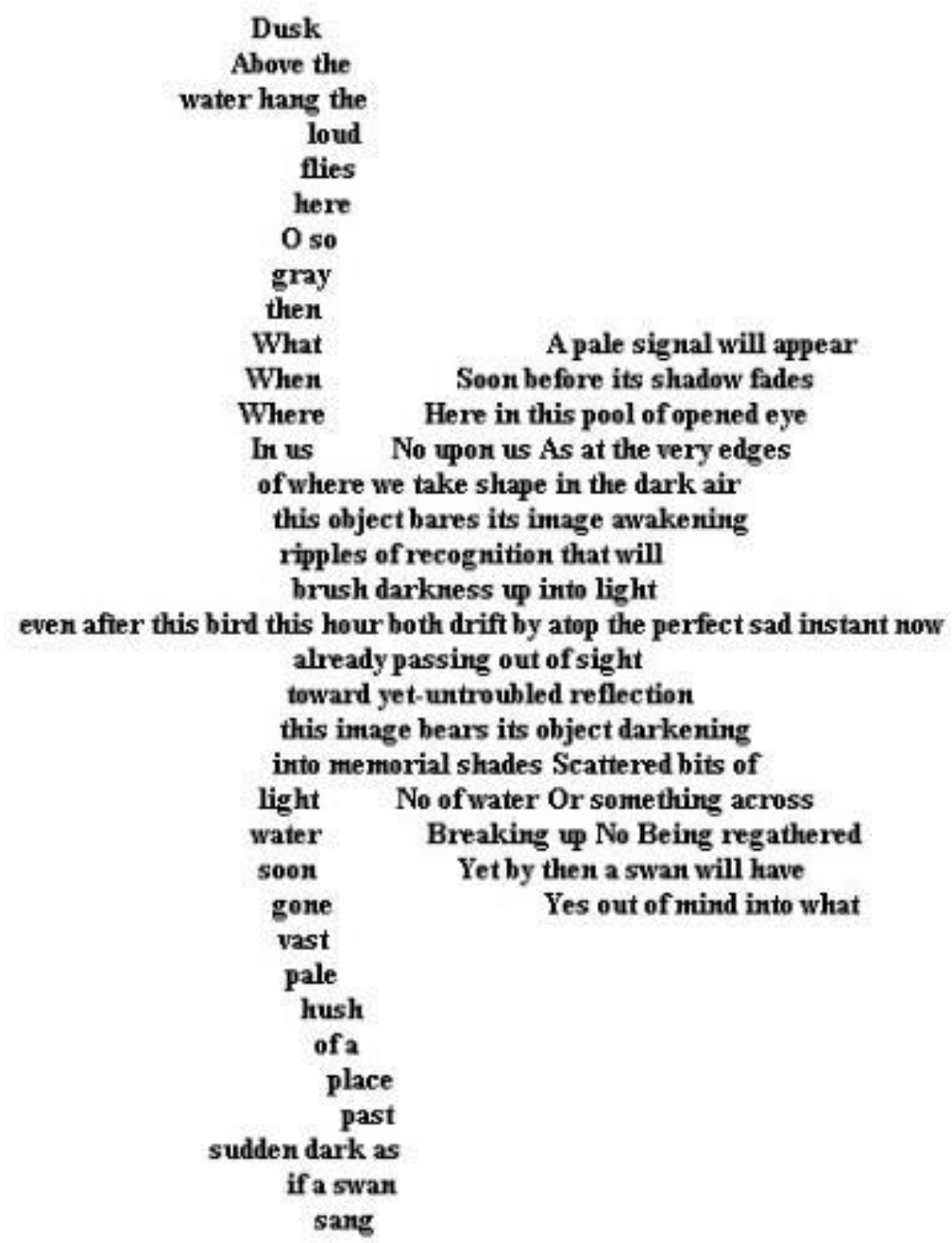

The title "Swan and Shadow" may carry an antithetical meaning of being happy and sad at the same time. For traditionally a swan embodies gorgeous things while a shadow embodies dark as well as enigmatic matters. The poem depicts the way a swan is showed to be a very 
unsophisticated and obviously attractive being nevertheless behind the dimness lies a thing quite profounder and dimmer. Hollander says "A pale signal will appear soon before its shadow fades". He is after conveying the idea of in what way something too minor can lead to an even greater detection, only if you pay near enough consideration. "No upon us as at the very edges of where we take shape in the dark air this object bares its image awakening ripples of recognition". Deeper in the meaning,Hollander is crystalizing an image of modification or possibly the idea of change from good to bad. The form of the poem is a story conveying the idea of how things altre to probably a younger crowd. Thus the subject matter is change, as well as "hidden secrets". So what is behind the story of the poem is that if something is lovely doesn't indicate that it's good. ${ }^{1}$

The poem is easy in its reading with no so much dificult words, yet there is a variety of choices in the way of reading the poem. It could be read in two or four ways. For it has two beginning as well as two endings. The first two options of reading is through the head of the swan, both possible the head of the swan and its shadow(the shadow of the head). So the begnning might be from "Dusk above the water hang the loud flies here " O so gray then what when where in us...." In this sense the other two ways of reading if through the sawn's wings. This time also through the wings above the water or their shadow or reflection in the water. Consequently the beginning would be " A pale signal will appear soon before its shadow faces Here in this pool of opened eye on Upon us at the very edges..." Such way of reading make it possible to comprehend the poem in two distinct directions. So there is a difficulty here in reaching the middle and end of the poem.

Another significant point in the poem is that it's being unpunctuated. For the words flow easily and smothly with no periods to end the sentence or any other punctuation mark. So, there is no definite indicator at the beginning or the ending of the words except the use of the capital letters by Hollander that might make a significant indicator of that. They signify a kind of guide to the reader so that he can move through in the poem. Actually it is a way or a technique used by the poet to add to the whole meaning of the poem. For the major theme in the poem is enigmatic nature and meaning of the shadow, and how far is it puzziling. May be his aim is to let the reader participate in understanding the poem the way he find it possible or the way they can approach it despite its mystery.

Also Hollander has another shape poem entitled "Graven Image" that deals with the image of a star that is outstanding and shines from so far away . 


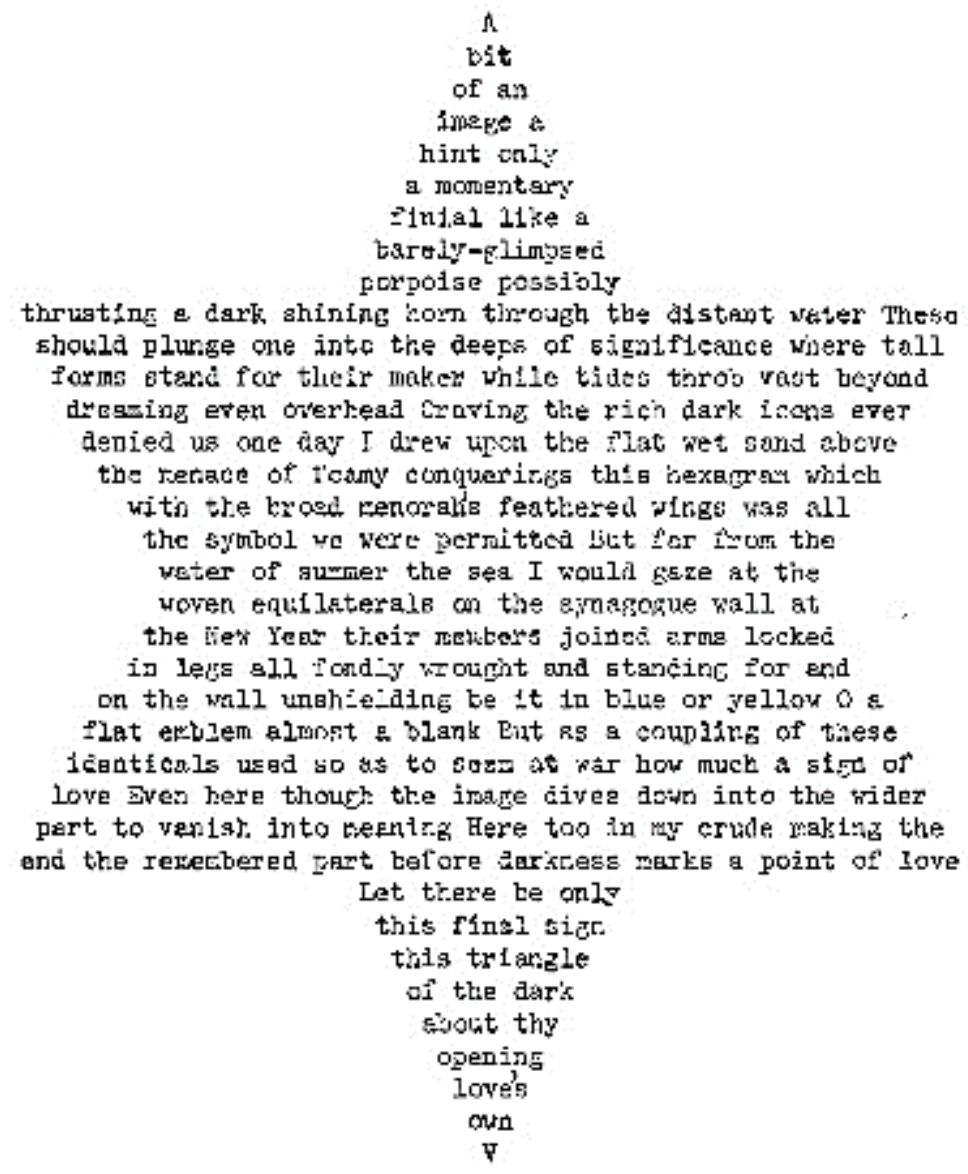

For Hollander poetry is a very interesting subject because it has a in graphic forms. The interest he got in this regard is taken from his awareness in versions from Yiddish language that uses pictorial alphabets of geometry makes him a poet who frequently wished to employ geometry and literature to each other. Besides he was well-skilled in drawing . Therefore, the passion as well as enjoyment that literature has, are to be found in Hollander's poetry. ${ }^{2}$ Thus, he wants to give the reader a full conception about the theme of the poem literally rather than figuratively. It is about an idol or about a guide who is going to shine and illuminate the darkness in us to know our right path in this life.

Hollander employs the shapes as well as forms to produce poems that has perfect geometrical forms like circle, heart, column, square as well as the combination of these shapes or the sake of conveying the pictorial depiction of their implications. Another instance of Hollander's employment of such practice is to be found in his "Crise De Coeur" It is in the shape of heart like that belongs to a human being. The poem is about the tale of a heart being mentioned by the heart itself. The narration is about the depressed tale of its lifetime and the heart attack he suffers 
from as the title might embody, therefore, he pleads the assistance from the listener of the poem:

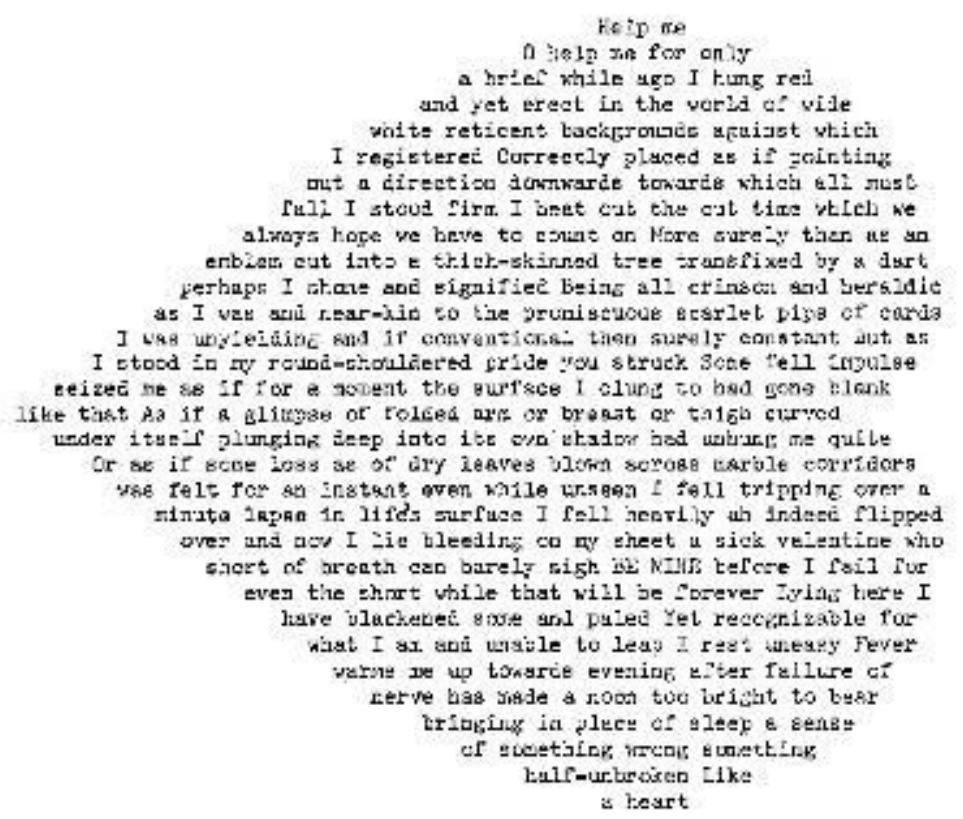

A significant aspect of shaped poetry is that the figures are of quite steady and alike shape of drawing, for example, when the poet is portraying a heart, there must be a sense of balance and resemblance between both parts of the heart. Also the lines of each part must be identical in both length and thickness. Consequently when a poet writes a geometrical verse poem, he has to produce a kind of equilibrium and harmony between parts and whole; this includes the number of the words and the lengths of the lines and how far they have got exceptional significance. Thus to compose a geometrical poem, the poet should use a similar procedure as if he is making geometrical shapes. In this poem Hollander intentionally shows his own idea the heart's suffering in the form of measurement as well as figure. The rhymes as well as the meters are made in equilibrium with each other and at the same time the number of the words used is counted up and they are the same in the balanced lines. Like for example Hollander used in the first line two words only and there is also two in the last line . So the balance is repeated. Furthermore, the poem is of thirty-one lines which fifteen of them are to be located in the higher part and the other fifteen are to be located in the lower part. There is also one line that functions as a balanced borderline that splits the poem into two parallel parts. $^{3}$

There is in the shape poem some sort of self-reflective picture within its form and content together. There are certain words in "Crise De Coeur," that are well-thought-out as the graphic word itself (in the first 
half) and the reflection of those same words in the other part of the poem. The words are to have shadow that reflects them as if the words are opposite for each other this is to be achieved through symmetry that enhances the tangibility of the words and their perception. To say that in the poem the word "surface" is accorded with the word "deep" is to strengthen the meaning of both as well as the shape of them. This occurs with other words like "seized" and "unhung" and words like "light" and "shadow". Such is for the sake of making harmony in the structure and in relation to the mind of the reader and the poet as well.

There is also another point in the poem related to shape like the geometrical structures and vocabularies of the poem that is used for the sake of drawing beautiful geometrical shapes to enhance both the splendors of meaning and truth that lurk behind them. These words aside from their extraordinary meanings in geometry, they have correspondent meaning to produce the identical meaning in the body of poetry. For example 'erect' means straight, 'wide' means extended, 'point' for the small measurement that measures font size, 'curve' means bend, and 'half' means one part of two equal parts. "Crise De Coeur," Hollander proves himself to be a master of shape as well as meaning.

Another poem by Hollander is his "Old Mazda Lamp," that is similar in its shape to the Roundel, Sphere and the Cylinder. He uses in the making of this poem two graphematic figures and deploys them to make a lamp-shaped verse :

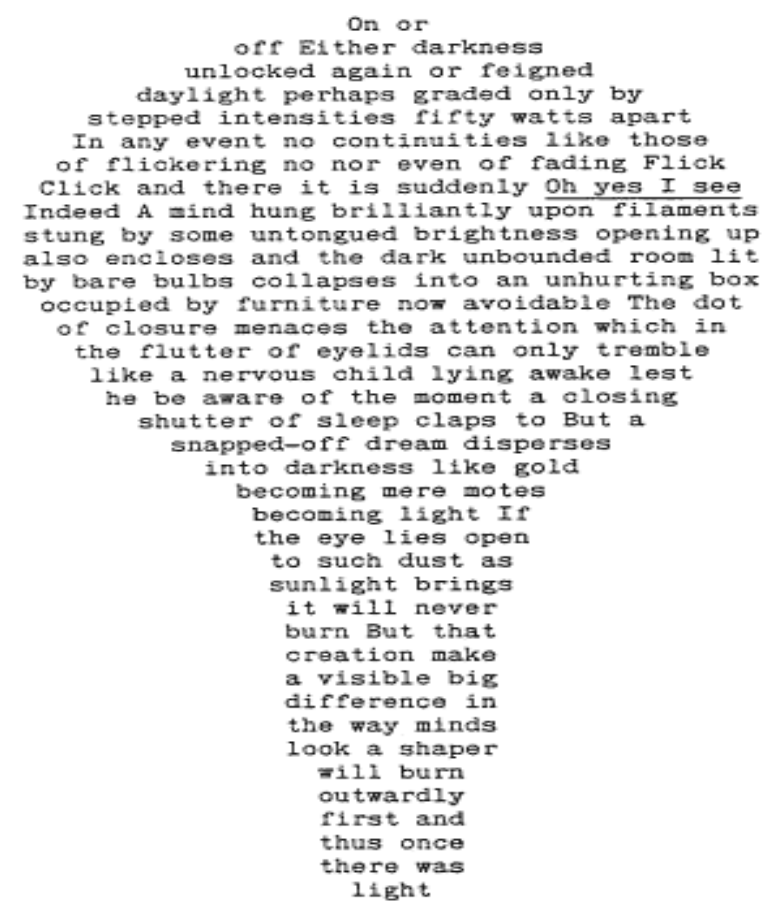


The poem is about the story of something, supposedly the lamp itself, who is telling the moment of turning on and off the lamp to produce the light and to illuminate the gloom. Such is done by manipulating forms and graphic imagery. Hollander did so to compare this situation to human being's mind. For a lighted room is likened with a well-informed mind both bright through the use of lamp symbolizing knowledge. Consequently, a simple (bare) mind symbolizes a room that is dark with no lamp to turn on and symbolically there is no knowledge. Doing so the poet is after conveying his viewpoint about a well-informed person through by using a visual image everyone realizes in the everyday life. Consequently Hollander's "Old Mazda Lamp" attracts the attention of primarily to the form and after that to the association as well as the idea carried in the poem. The management of the words is as well as their collection are of bewildering significance. For it is a poem of the words that are intermixed to make a form as well as after that for the sake of transferring the meaning. It is clear that, in a lamp, the sharp point on the top is the initial and the final one as well where the glass of the lamp has been accomplished. Thus to abolish this high-pitched idea is equivalent to abolishing the whole lamp and therefore, its construction. This idea then is the furthermost energetic fragment, functioning a considerable role that is the close and at the same time the commencement. Furthermore, the first as well as the second lines, there is the use of the words 'on' and 'off', they are the major words in the connotation being very severe and trivial words in size at the highest of the lamp itself. The poet makes the reader out on an expedition with '[o]n' then finishes the journey with 'light' that is why of being on; this makes the reader have an evaluation to the symmetry in the connotation of the poem that functions similar to a cyclical system prevailing in graphematic shapes. ${ }^{5}$

So the number of the lines is thirty-eight and the length of these lines alternate as the actual size of a lamp rises or falls, so the poet can make a harmony due to the distinctiveness of the structure of the poem. In a very interesting way the measurement of the poem with the measurement of a actual lamp if it is to be made, one can find the only alteration would be the grade of measure. In other words, the poem is completely a match to the lamp but the scale is dissimilar. In a very visual way, the poet tries to show or depict the numerous fluctuations of life of a lamp to convey a too profound perception of life of a man. He desires presenting the pictorial power of cognizance so that he can transport the meaning in an direct way. Comparatively, to turn a lamp off and on, that is a very perceptible phenomenon in human's day-to-day life, is so similar to what Hollander employs to express his point of view but through shape poetry. ${ }^{6}$ 
Another example of Hollander's graphitic poem is the poem entitled "Kitty" and is subtitled as "Black domestic shorthair where he talks about the theme of independence and innovation:

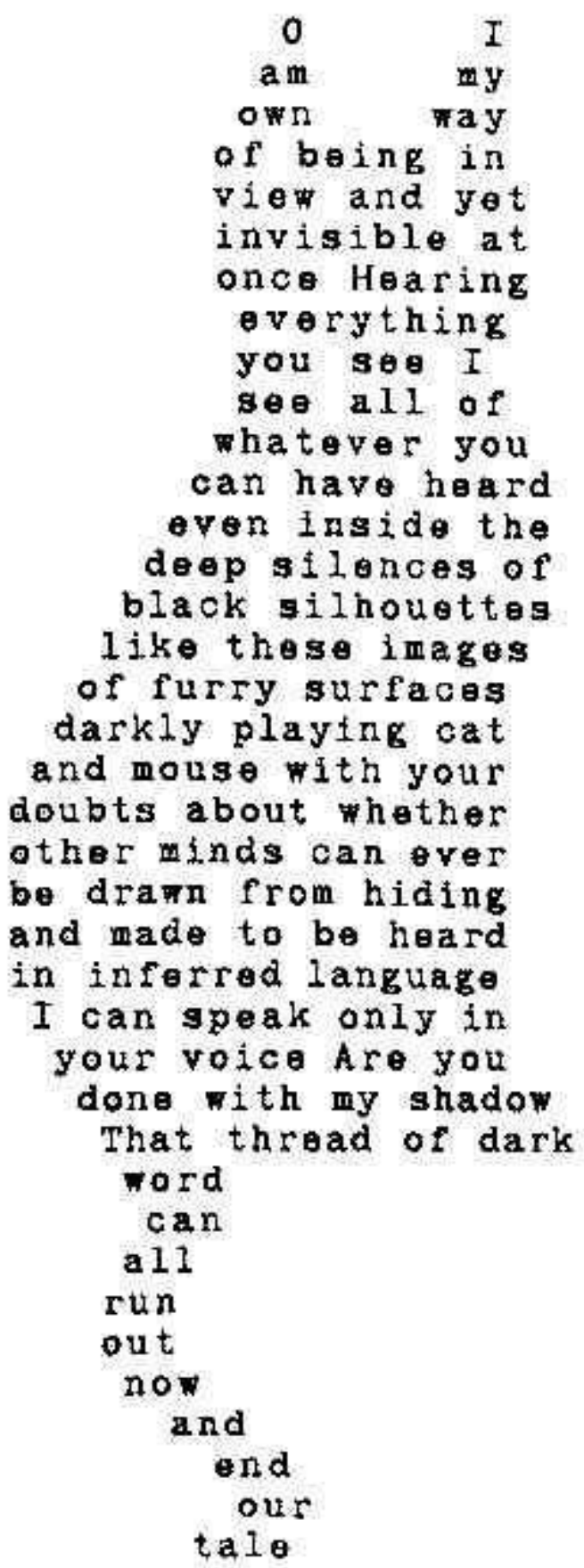


And another one of the same shape with different meaning is the following:

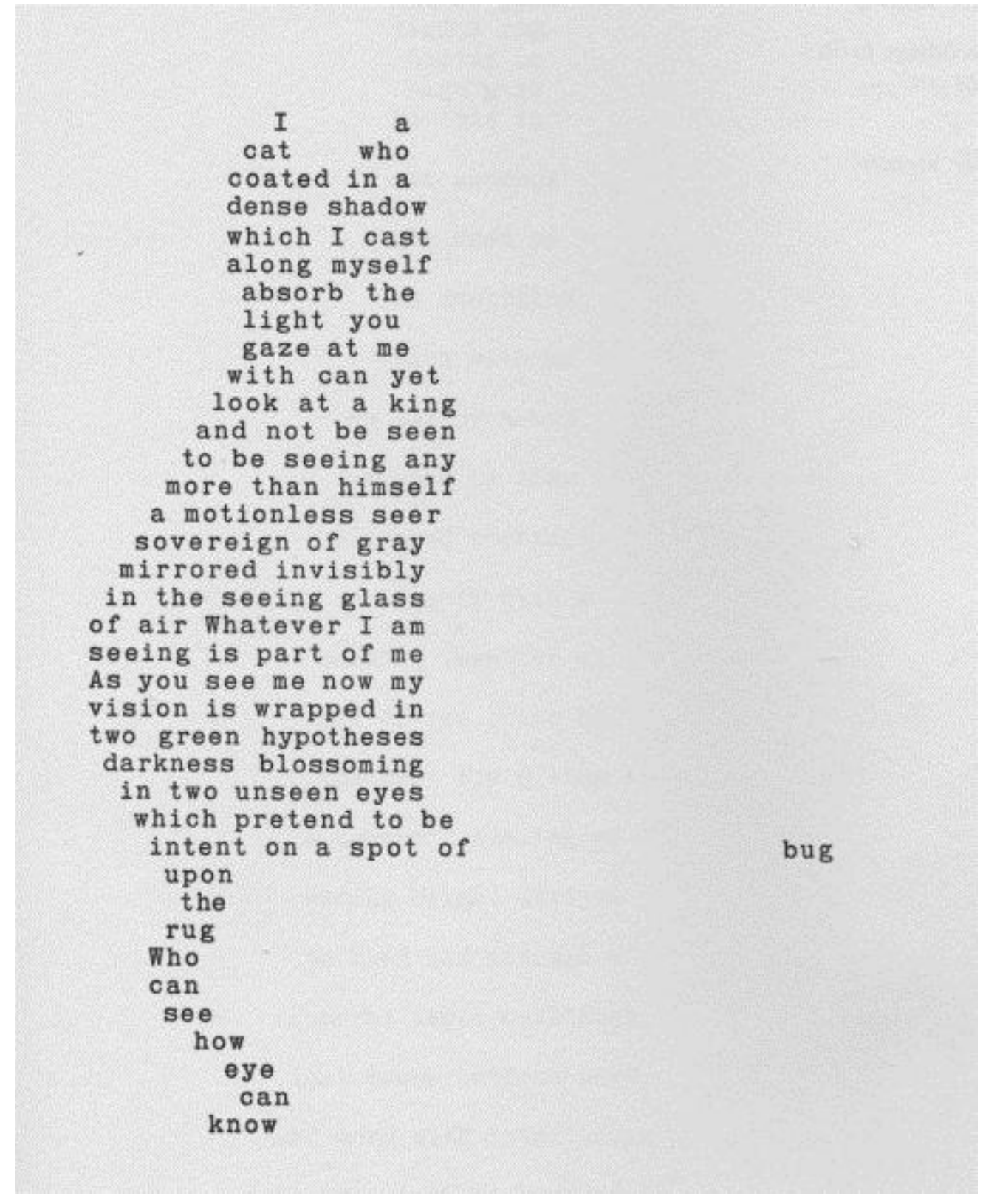

In this poem Kitty and Bug one might find self-explanatory style in its simplicity for it is the core of shape poetry. The cat's unpunctuated, almost stream-of-consciousness considerations suits into a physical 'cat' shape, while the bug in sever contrast and is just a 3-letter word near the edge of the page. ${ }^{7}$

Another example is in the shape of a cup, a poem that might carry many meanings and might be in more than one shape. If we consider it a cup, it might refer to a religious idea about the wholly grail and how 
religion is related to truth or it might refer to a poem, the cup any poet might drink and being inspired, just like a muse, to help creating a poem that reflects nothing but truth which might refer to love or any other kind of truth. Also the shape of the poem might be a combination of different shapes like a crown wearied by kings or gods and how far is it pretentious. Or a column of common or even rare clay that carries a cup which is empty now. Then he morns that its being empty, and wishes it to be filled which metaphorically means forming an idea about a certain poem that is so beautiful because it is about you, his love. This clearly and skillfully presented by starting the poem with I and ending it with you, the poem is about love between him and his beloved.

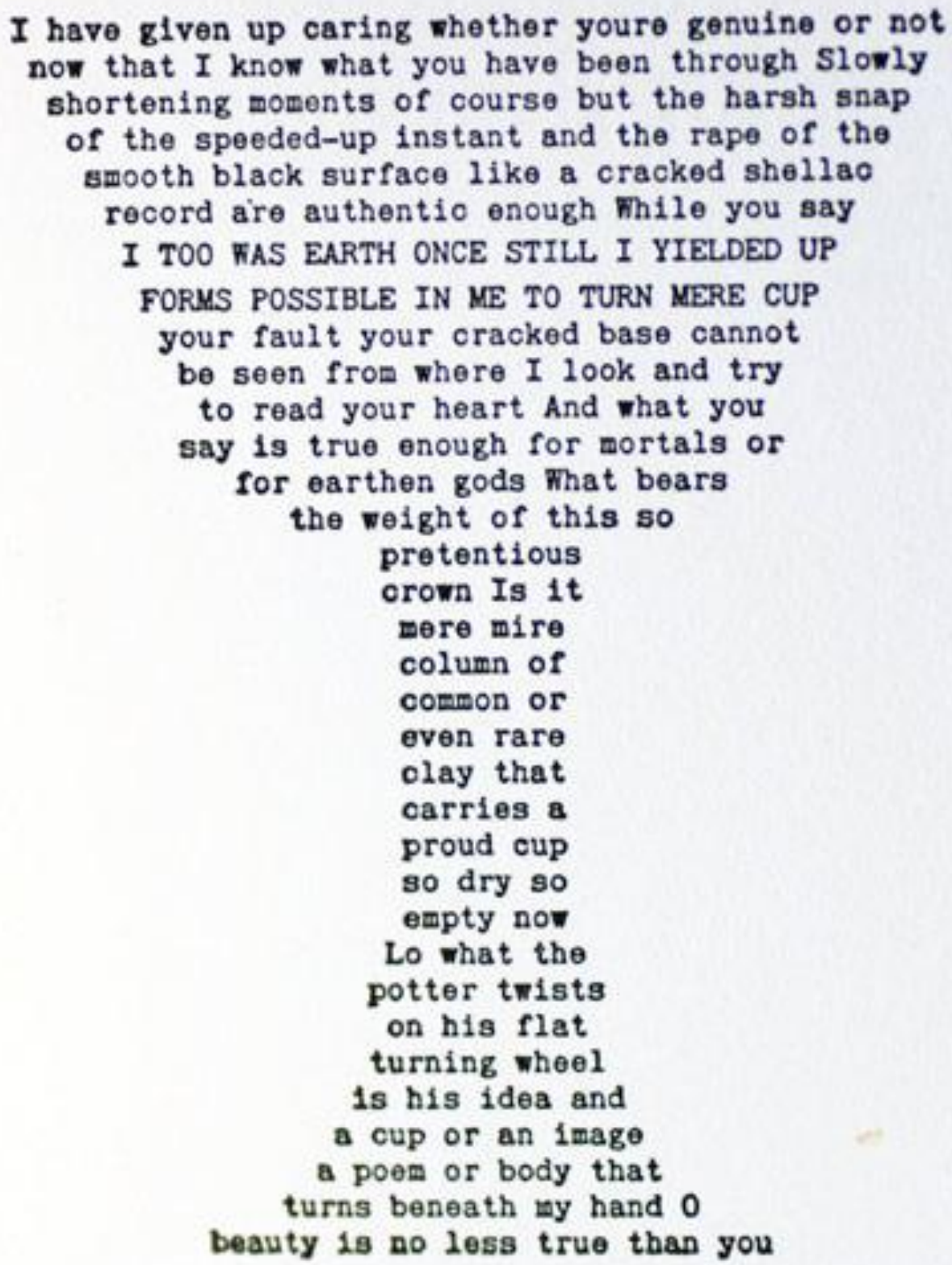




\section{Notes:}

${ }^{1}$ B.C.wolf, "Venerable poet's Words to a Pop Music Beat." Interview, The New York Times, February, especial ed. Vol. 2:10 n. p.

${ }^{2}$ Mehrdad Moazami Goudarzi, Leila Baradaran Jamili and Bahman Zarrinjooee, "A Journey to Poetry of Geometrical Shapes from the Ancient Times to Poetry of John Hollander" , 2014JNAS Journal-2014-3-7/771776.

${ }^{3}$ Birken M. and Coon AC., DiscoveringPatterns in Mathematics and Poetry(New York: Rodopi,2008),98.

${ }^{4}$ Ibid.

${ }^{5}$ Goudarzi, 775.

${ }^{6}$ J. Swansburg, "At Yale, Lessons in Writing and Life." The New York Times, Vol.5: 7. 3-13.

${ }^{7}$ Ibid.

\section{Conclusion:}

shape poetry or concrete poetry is the type of poetry that its visual form on the page is a vital part of the poem. Such poems, carry the joy of a new form that combines the forms of the poems as well as their implications in a correlated way to each other. Thus to read such poem each, shape or content, it is probable to reach one through the other. Hollander's construction of poems is derived from the geometric forms . Therefore by considering some of the shapes to be the basic figures to his poems, John Hollander used them as structures and then created his meaning according to this structure. His poems are completely geometrical with balanced forms for the sake of helping the reader to comprehend the meaning even without a complete reading of the poem. The graphic effect leads to an understanding of this type of poetry. 


\section{Bibliography:}

Goudarzi, Mehrdad Moazami Leila Baradaran Jamili and Bahman Zarrinjooee , "A Journey to Poetry of Geometrical Shapes from the Ancient Times to Poetry of John Hollander" , 2014JNAS Journal-2014-3-7/771-776.

M. ,Birken and Coon AC., DiscoveringPatterns in Mathematics and Poetry.New York: Rodopi,2008

Swansburg, J. "At Yale, Lessons in Writing and Life." The New York Times, Vol.5: 7. 3-13.

wolf, B.C. "Venerable poet's Words to a Pop Music Beat." Interview, The New York Times, February, especial ed. Vol. 2:10 n. p. 